\title{
Description Of Ecg Recycle And Coronary Angiography In Coronary Heart Disease Patients In Catheries Heart Of dr. Iskak Tulungagung
}

\author{
Karmiati $^{1}$, Sutrisno ${ }^{2}$ \\ ${ }^{1} d r$ Iskak Hospital, Tulungagung, East Java, Indonesia \\ ${ }^{2,}$ STIKes Surya Mitra Husada, Kediri, Indonesia) \\ Corresponding author : alyamila7@gmail.com
}

\begin{abstract}
Background: Coronary heart disease is a major health problem in almost every country in the world and contributes to about $30 \%$ of all deaths worldwide. Proper diagnosis in patients with coronary heart disease will determine the accuracy of the procedure and will affect the patient's healing and prognosis.

Purpose : This study aims to describe the picture of ECG and coronary angiography in patients with coronary heart disease.

Methods : The design of this study was descriptive with the patient population of coronary heart disease in the cardiac catheterization room of RSUD dr. Iskak Tulungagung. The sample size was 35 respondents taken with acidental sampling. The variables in this study are ECG image and coronary angiography results. Methods of data collection using observation sheet. The results showed 13 respondents $(37.14 \%)$ results of ECG image injuri. While the results of angiography showed $27(77.14 \%)$ of respondents there was a significant stenosis.

Result : The result of research also got difference of result between ECG image and Coronary angiography where the respondent that picture ECG and Coronary Angiography fit as many as 23 respondent whereas between ECG picture and Coronary Angiography not suitable as much 12 respondents.

Conclusion : In accordance with the number of accuracy of ECG in diagnosing coronary heart disease patients who ranged between $55 \%$ while in angiography accuracy rate $99 \%$ then can be drawn conclusion diagnostic patients with coronary heart disease using EKG can be a mistake of diagnosis by $45 \%$ compared angiografi which only $1 \%$.
\end{abstract}

Keywords : Coronary angiography, Coronary heart disease, Electrocardiogram

Received: February 03, 2018; Revised February 24, 2018; Accepted March 10, 2018

How to Cite: Karmiati., \& Sutrisno. (2018). Description Of ECG Recycle And Coronary Angiography In Coronary Heart Disease Patients In Catheries Heart Of dr. Iskak Tulungagung. Journal Of Nursing Practice. 1(2). 26-32 


\section{BACKGROUND}

Cardiovascular disease, especially coronary heart disease, is a major health problem in almost every country in the world and contributes to about $30 \%$ of all deaths worldwide. The prevalence of national coronary heart disease based on Riskesdes 2013 is $1.5 \%$. Riskesdes 2013 results show the prevalence of coronary heart disease based on doctor diagnosis of $5 \%$, while based on symptoms of $1.5 \%$. The mortality rate from coronary heart disease in Indonesia reaches 53.5 per 100,000 population. (www.depkes.go.id). The incidence of coronary heart disease found in hospitals dr. Iskak Tulungagung through the ER in 2016 as many as 374 cases, where patients entered with diagnosis UAP 54 cases, NSTEMI 120 cases and STEMI 200 cases. (Medical Record RSUD Dr. Iskak, 2016)

Coronary heart disease is a narrowing or blockage of coronary artery blood vessels called coronary blood vessels. As with any body organ, the heart also needs nutrients and oxygen to pump blood throughout the body, the heart will work well if there is a balance between supply and expenditure. If the coronary arteries are blocked or narrowed, the blood supply to the heart will decrease, resulting in an imbalance between the need and supply of nutrients and oxygen, the greater the percentage of coronary artery narrowing the reduced blood flow to the heart, resulting in chest pain. (UPT - Information Center for Lipi Food \& Health Technology, 2009).

Early diagnosis of coronary heart disease based on risk stratification approach including history of disease, physical examination and investigation is needed for diagnosis to determine the accuracy of the procedure and will ultimately improve patient outcome and prognosis. Investigations of coronary heart disease may be non invasive and invasive. The non invasive examination such as EKG, treadmill, laboratory, nuclear and MRI. While invasively performed with coronary angiography.

ECG is an important diagnostic tool for diagnosing disorders such as atrial and ventricular hypertrophy, myocardial ischemia and infarction, pericarditis, the effects of several treatments, especially digitalis and anti-arrhythmias, and for assessing pacemaker function. The use of EKG is still the most important and fastest way of examination for both the initial diagnosis and evaluation of clinical course of coronary heart disease. ECG is important in the identification and management of coronary heart disease especially in patients with acute myocardial infarction. A detailed analysis of the ST segment elevation pattern may influence the patient's treatment decision. Early and accurate identification of arteries associated with infarction of the ECG can help predict the number of myocardium at risk and assist in making decisions about the urgency of patient revascularization and therapy. Tamine-tamda reperfusion ECG is an important marker of coronary blood flow and patient prognosis. EKG is also important to identify the emergence of conduction abnormalities and arrhythmias that affect both short-term and long-term patient outcomes.

Coronary angiography is a standard gold in identifying constriction of coronary arteries associated with coronary heart disease. The purpose of coronary angiography is to determine the anatomy and degree of coronary artery lument obstruction so that it can assess the severity of coronary heart disease. This examination may also be performed in patients with an unclear diagnosis of coronary heart disease and can not be excluded by non-invasive testing. Invasive coronary angiography also facilitates the determination of therapy in which intervention therapy (Percutaneous Coronary Intervention) can be done in conjunction with diagnostic procedures. Invasive coronary angiography is highly recommended in patients with acute myocardial infarction with ST segment elevation or without elevated ST elevation. Thus high-risk patients can be identified quickly so that no delay in handling. In patients with STEMI Diagnostic Coronary Angiography should be 
done immediately followed by Percutaneous Coronary Intervention. Percutaneous Coronary Action Procedures Rapid intervention can restore heart muscle to its original state, shorten treatment time and improve patient prognosis. In 2016, Coronary Diagnostic Coronary Angiography patients were 234 patients. (Medical Record RSUD Dr. Iskak, 2016)

Based on the above description, the formulation of this research problem is "Overview of ECG Record and Coronary Angiography in Coronary Heart Disease Patients in Cardiac Catheterization Room of RSUD dr. Iskak Tulungagung ".

\section{OBJECTIVE}

Knowing the Overview of ECG Record and Coronary Angiography Results on Coronary Heart Disease Patients in Cardiac Catheterization Room of RSUD dr. Iskak Tulungagung.

\section{METHODS}

The research design used is descriptive research to get an overview of the results of ECG reading and Angiography results in patients with coronary heart disease in the Cardiac Catheterization Room Hospital dr. Iskak Tulungagung.

The samples of this study were all patients of coronary heart disease performed by ECG and Coroner angiography in the cardiac catheterization room of dr. Iskak Tulungagung on 1 to 30 June 2017 as many as 35 respondents. The sampling technique used in this research is accidental sampling technique.

\section{RESULTS}

This research was conducted in Cardeter Catheterai Heart Hospital dr. Iskak Tulungagung on June 1 to June 30, 2007, with the number of respondents 35. The characteristic of respondents based on general data can be explained as follows:

Characteristic of respondents by sex is found most of the respondents of male gender is as much as 27 respondents or $77 \%$, Characteristics of respondents by age is found most of the respondents umumrnya $>50$ years as many as 23 respondents or $66 \%$, Characteristics of respondents based on education obtained almost half of respondents with high school education as many as 15 respondents or $43 \%$, Characteristics of respondents based on medical history obtained almost half of the respondents have a smoking health history of 24 respondents or $48 \%$, Characteristics of respondents based on previous illnesses obtained most respondents ever went to the heart poly with coronary heart disease complaints that is as much as 22 respondents or $65 \%$.

While the characteristics of respondents based on variables can be explained as follows:

a Results of ECG picture

1. Degree of ECG

Degree of ECG in Coronary Heart Disease Patients in IDIK RSUD dr. Iskak Tulungagung obtained most of the degree of EKG is injury that is as much as 13 respondents or $37.14 \%$.

2. Location of ECG Disorder

Location of ECG Abnormalities in Coronary Heart Disease Patients in IDIK RSUD dr. Iskak Tulungagung obtained most of the location of ECG abnormalities is the interior of 12 respondents or $40 \%$.

b Coronary Angiography Results

1. Degree of Stenosis 
Degree of Stenosis in Coronary Heart Disease Patients in IDIK RSUD dr. Iskak Tulungagung obtained most degree of Stenosis $>50 \%$ which means significant as much as 27 respondents or $77.14 \%$.

2. The location of Stenosis

Locations of Stenosis in Coronary Heart Disease Patients in IDIK RSUD dr. Iskak Tulungagung obtained most of the location of the stenosis is LAD (Left Artery Descenden) that is as much as 23 respondents or $54.76 \%$.

3. Number of Stenosis Locations

Number of Stenosis Locations in Coronary Heart Disease Patients in IDIK RSUD dr. Iskak Tulungagung obtained most of the number of stenosis location is SVD (Single Vesel Desease) that is as much as 16 respondents or $45.71 \%$.

c Comparison of ECG Results and Coronary Angiography

1 Respondents who described ECG and Coronary Angiography as many as 23 respondents or $65.71 \%$

2 Respondents who describe ECG and Coronary Angiography does not match as many as 12 respondents or equal to $34.28 \%$

\section{DISCUSSION \\ Overview of ECG in Coronary Heart Disease Patients in IDIK Room RSUD dr. Iskak Tulungagung}

The results of the study in Table 4.1 shows that the picture of ECG in patients with coronary heart disease in IDIK RSUD dr. Iskak Tulungagung obtained most of the degree of EKG is injury that is as much as 13 respondents or $37.14 \%$.

The basic feature of injury is the typical ST segment elevation (upward convex) (Pratana, 2006). The presence of ST segment elevation is a major sign of acute myocardial injury. In a normal ECG, the ST segment should not be elevated more than $1 \mathrm{~mm}$ in standard leads or over $2 \mathrm{~mm}$ in a precordium lead. In acute injury, the ST segment on the leads facing the injured area is elevated. The ST segment elevation also has a downcrop or cove shape and joins invisibly with T waves (Hudak and Gallo, 2012).

According to AHA (American Heart Associaton) major risk factors for coronary heart disease include smoking, hypertension, elevated cholesterol levels, diabetes mellitus, increasing age, obesity and family history of coronary heart disease. Based on medical history in this study obtained almost half of respondents ie sebayak 24 respondents or $48 \%$ of smoking. Smoking is the most important risk factor for coronary heart disease.

Smoking has a major impact on myocardial infarction and all causes of death. The loose thromboses in the coronary arteries will lead to implantation of the arteries so that the patient has acute myocardial infarction. Patients with acute myocardial infarction of the ECG image will be found in ST segment elevation.

\section{Overview of Coronary Angiography Results in Coronary Heart Disease Patients in IDIK RSUD dr. Iskak Tulungagung}

The results of the study in Table 4.3 shows that the degree of stenosis in patients with coronary heart disease in IDIK RSUD dr. Iskak Tulungagung obtained most degree of stenosis $>50 \%$ which means significant as much as 27 respondents or $77.14 \%$.

As mentioned above, according to AHA (American Heart Associaton) major risk factors for the occurrence of arterisklerotik in patients with coronary heart disease include 
smoking, hypertension, elevated cholesterol levels, diabetes mellitus, increasing age, obesity and family history of coronary heart disease.

From the results of research based on age, most of the respondents were 50 years old as many as 20 respondents or $66 \%$. According to Yani (2015) the most important risk factor in the incidence of heart and blood vessel disease is age with research results in the age above 55 years have a statistically proven risk associated with heart disease and blood vessels. This is in line with the theory that age is an irreversible risk factor in heart and blood vessel disease.

Comparison of ECG Results and Coronary Angiography Results on Coronary Heart Disease Patients in IDIK RSUD dr. Iskak Tulungagung

Based on Table 4.7 on the comparison of ECG and Coronary Aillography on the Coronary Heart Disease Patients in IDIK RSUD dr. Iskak Tulungagung obtained most $(65.71 \%)$ or as many as 23 respondents according to the ECG picture and Angiography Results.

Coronary artery is divided into two namely Right Coroner Artery (RCA) and Left Coroner Artery (LCA). LCA is divided into 2 namely Left Artery Descenden (LAD) and Left Circumflex (LCX). LAD supplies the heart muscle Anterior Ventricular Septum, anterior left ventricle and Heart apek. If there is a blockage in the LAD and resulting damage to the heart muscle will look kelianan on the ECG in V1-V4. LCX supplies the left atrial heart muscle, left ventricular lateral wall, posterior wall of the left ventricle. If there is damage to the heart muscle will be seen abnormalities of ECG on V4-V6 and I, AVL. The right coronary artery supplies the heart muscle in the right atrium, right ventricle, the posterior ventricle septum, the left inferior wall of the left ventricle. If there is damage to the heart muscle will look eccentric EKG pad II, III, AVF (Hudak and Gallo, 2012).

Based on table 4.7 also found a small number (12 respondents) or as much as $34,28 \%$ not fit between the ECG picture and angiography results. Research data obtained 2 respondents who diagnosed coronary heart disease but obtained normal ECG results and angiografinya also normal. This is probably because non-coronary clinical causes can be other disorders in the thoracic wall structures such as muscle, bone, nerve or lung. In patients with hypertension chest pain can be caused by non hypertension angina due to high afterload so that heart work increases. It may also be due to spasm of the coronary arteries. In patients with diabetes mellitus can occur neuropathy so that there is a sensation of chest pain that can be caused by the neuropathy.

Research data obtained 3 respondents normal EKG whereas angiografinya results obtained significant stenosis. EKG shows functional activity of the heart. While angiography indicates the state of coronary artery anatomy. If a normal ECG is found whereas significant stenosis is obtained in angiography it is possible that blood supply to heart cells is good so there is no damage to cardiac cell or heart perfusion disorder despite significant stenosis in the coronary artery, to obtain a normal ECG picture.

The research data obtained 6 responders ECG picture is not normal but normal angiografinya results. In accordance with the number of accuracy of ECG in diagnosing coronary heart disease accuracy ranges between $55 \%$. While the angiography accuracy of $99 \%$. So it can be concluded that the diagnosis of coronary heart disease by using EKG can occur a misdiagnosis of $45 \%$ while the diagnosis of coronary heart disease by using angiography can be a fault diagnosis of only $1 \%$.

The sensitivity of an EKG may be influenced by non coronary factors such as BER, Infection or non coronary arrhythmias. In cases of infections such as pericardiosynthesis, there may be a change in ECG picture although angiography is normal. Likewise with non coronary arrhythmia, ECG in patients can be obtained ischemic images without a blockage 
in the coronary arteries. Likewise in patients who experience spasm in the coronary arteries at the time of ECG will get abnormalities in the picture of ECG.

\section{CONCLUSION}

Based on the results of research and discussion about ECG recording and Coronary Angiography images on Coronary Heart Disease Patients in IDIK RSUD dr. Iskak Tulungagung can be concluded:

1. Most of the respondents $(37.14 \%)$ or as many as 13 respondents from coronary heart disease patients get the picture of injury EKG.

2. Almost all respondents (77.14\%) or as many as 27 respondents from coronary heart disease patients who performed angiography got stenosis more than 50\% (significant).

3. Comparison of ECG and coronary Angiograi images in patients with coronary heart disease:

a Corresponding ECG and Coronary Angiography as many as 23 respondents or $65.71 \%$.

b An inappropriate ECG and Coronary Angiography of 12 respondents or $34.28 \%$.

\section{REFERENCES}

Dharma, S. (2010). Sistematika Interpretasi EKG : pedoman praktis. Jakarta. EGC

Gabriel.J.F. (2001). Fisika Lingkungan. Jakarta. Hipokrates

Hampton, J.R. (2006). Dasar-dasar EKG edisi 6. Alih bahasa A. Samik Wahab. Jakarta. EGC

Hastono, S.P. dan Sabri, Luknis. (2010). Statistik Kesehatan. Jakarta. Raja Grafindo Persada.

Hendy. (2009). Penyakit Jantung Koroner. http://heqrisonline.blogspot.com. Diakses tanggal 23 Januari 2017.

Hudak, C.M. dan Gallo, B.M. (2010). Keperawatan Kritis. Jakarta. Penerbit Buku Kedokteran.

James, J.Baker. C and Sivain.H. (2008). Prinsip-prinsip Sains untuk Keperawatan. Jakarta.Erlangga

Karim, S \& Kabo, P. (2006). EKG dan Penanggulangan Beberapa Penyakit Jantung untuk Dokter Umum.Jakarta. Balai Penerbit FKUI.

Morton, P.G., Fontaine, Dorrie, Hudak, C.M. dan Gallo, B.M. (2012). Keperawatan Kritis. Jakarta. Penerbit Buku Kedokteran.

Munawar, M dan Sutandar, H. (2002). Buku Ajar Kardiologi. Jakarta. EGC

Muttaqin, Arif. (2008). Asuhan Keperawatan Klien Gangguan Sistem Kardiovaskuler. Jakarta. Salemba Merdeka 
Muttaqin, Arif. (2009). Asuhan Keperawatan Klien Gangguan Sistem Kardiovaskuler.Jakarta. Salemba Merdeka

Oktaviono, H.Y., Subagjo, A., Lefi, A. Pratanu, I. (2013). Manajemen Komprehensif Penyakit Jantung Koroner. Surabaya. Universitas Airlangga

PPNI. (2009). Penyakit Jantung Di Indonesia. http://www.inna-ppni.or.id. Diakses tanggal 15 Januari 2017

Pratanu, S. (2004). Kursus Elektrokardiografi. Surabaya.Karya Pembina Swajaya.

Soeharto, Iman. (2004). Penyakit Jantung Koroner dan Serangan Jantung. Jakarta.Gramedia Pustaka Utama.

Tiani, et al. (2015). Determinan Penyakit Jantung dan Pembuluh Darah Pasien Poli Jantung Pembuluh Darah Pasien Rawat Jalan Poli Jantung dan Poli Penyakit Dalam RSD dr. Soebandi Jember. E-Jurnal Kesehatan, vol. 3. 